\title{
The Individual and Structural Change in the International Legal System
}

Kate Parlett

\section{Introduction}

The international law of today arguably bears little relation to the international law of the $19^{\text {th }}$ century. At that time, international law was generally conceived as a body of rules and forms of conduct applicable to states in their relations with each other 11 During the $20^{\text {th }}$ century, a more multifaceted and cosmopolitan view of legal relations in international law emerged.

There is now little controversy surrounding the notion that international law is not exclusively concerned with inter-state relations, nor the proposition that individuals have a certain status in international law as the beneficiaries of rights and the bearers of obligations-indeed, that they are 'subjects' of international law as the notion of 'subjects' has been defined. There has thus been a significant shift in attitudes towards the individual and individual rights over the period since Vattel $]^{2}$

Nevertheless, there are two aspects of the debate concerning individuals in the international legal system that remain controversial.

The first is the question of the motivating force for this structural change in international law. Can it be explained on pragmatic grounds, or is it a product

BA/LLB (Hons), University of Queensland; LLM (Hons), PhD (Cantab); Associate, Freshfields Bruckhaus Deringer LLP, Paris, France; <kate.parlett@freshfields.com>. This paper draws upon research published in The Individual in the International Legal System: Continuity and Change in International Law (CUP, 2011) and presented at the CJICL's inaugural conference in Cambridge in May 2012.

1 Cf H. Grotius, The Rights of War and Peace (1625, R. Tuck (ed)) (Liberty Fund, 2005), Book I, Chapter I, XIV, at 162.

2 E. de Vattel, The Law of Nations or, Principles of the Law of Nature Applied to the Conduct and Affairs and Nations and Sovereigns (1758, B. Kapossy and R. Whatmore (eds)) (Liberty Fund, 2008), Introduction, $\$ 3$, at 67. 
of theoretical discourse championing individualism over the construct of the state?

The second is whether, normatively, the move towards individualism in international law is to be welcomed in all its forms, or whether some of the aspects of the more traditional, $19^{\text {th }}$ century conception of international law, still serve a useful purpose, and should be conserved rather than condemned.

There is a third controversy to which these structural changes have given rise, concerning the way in which engagement in the international legal system is measured. Traditionally, engagement in international law has been measured by international legal personality, or the doctrine of 'subjects'. In the international legal system of the $19^{\text {th }}$ century, this was basically a categorization of states versus all others, since international law was traditionally conceived as bearing only upon inter-state relations. In today's international legal system, it is uncontroversial to suggest that entities other than states (including natural persons) are subjects of international law. But their qualitative status differs, such that it is questionable whether the doctrine of subjects serves a useful purpose any longer.

Bearing in mind these three controversies, the paper is structured in four parts. First, the development of the position of the individual in the international legal system is summarised, using a historical perspective. Second, the forces or motivations which appear to have driven this structural change in the international legal system are examined. Third, the controversy surrounding the doctrine of 'subjects' of international law as the measure of engagement in the international legal system is considered. Fourth and finally, the normative value of the apparent move towards individualism and away from the state, which appears to be occurring at the present time, is discussed.

\section{Historical development of the position of the individual in the international legal system}

The method I have used to assess structural change in the international legal system is to take a historical perspective, i.e. to look at developments as and when they occurred and to consider their impact on the structures of international law, bearing in mind the prevailing conceptualisations of international law at that time. 
However, taking a historical approach begs the question of when history began. Many refer to Grotius as the father of international law and begin their assessment with his work. I chose rather to begin in the $19^{\text {th }}$ century, when there was emerging consensus on a conception of international law or the law of nations' as a law between states. Thus my history begins with the work of Emer de Vattel in the mid-18th century, whose approach came to occupy a dominant position in doctrine from the late 18 th until the mid- $19^{\text {th }}$ century

It is true that writers pre-dating Vattel had a broader conception of the jus gentium. Hugo Grotius (1583-1645) in De jure belli ac pacis libri tres referred to the 'law of nations' or jus gentium; he did not envisage a law exclusively concerned with relations between states, but rather a law between the rulers of nations-those exercising public power-and between groups of citizens or private individuals not in a domestic relation to each other ${ }^{4}$ Grotius did not see the state as a separate juridical entity, but as a body of free Persons, associated together ${ }^{5}$ under the personal leadership of the ruler ${ }^{6}$ Grotius' law of nations was not an inter-state law, but an inter-individual law, applicable on a universal basis? In this respect his work followed a leading tradition of medieval scholastic thought. Medieval natural law was seen to be all-embracing; it regulated the natural and social life of all, applying between rulers as well as between private individuals ${ }^{8}$ Similarly Vitoria's idea of an international society was based on the concept of a universal community which encompassed all mankind, an organised community of peoples which were

3 See e.g., A. Nussbaum, A Concise History of the Law of Nations (Macmillan, 1964), at ix.

4 P. Haggenmacher, Grotius et la doctrine de la guerre juste (Presses Universitaires de France, 1983), at 541-3; E. Jouannet, Emer de Vattel et l'émergence doctrinale du droit international classique (Pedone, 1998), at 263, 361; J. Crawford, International Law as an Open System (Cameron May, 2002), at 19. Hugo Grotius is often said to be the founder of modern international law: see L. Oppenheim, International Law: A Treatise (Longmans, Green \& Co, 1905), at 77; H. Lauterpacht (ed) International Law: A Treatise, by L. Oppenheim (Longmans, 1955), at 91; H. Lauterpacht, 'The Grotian Tradition in International Law', (1946) 23 BYIL 1, at 51. But more recently this has been subject to criticism and dismissed as an exaggeration: see R. Jennings and A. Watts, Oppenheim's International Law (Longmans, 1992), at 4; H. Waldock (ed), J L Brierly, The Law of Nations: An Introduction to the International Law of Peace (Clarendon Press, 1963), at 28; D. Kennedy, 'Primitive Legal Scholarship', (1986) 27 Harvard International Law Journal 1 , at 77 .

5 Grotius, supra note 1, at 162.

6 Haggenmacher, supra note 4, at 541-3; E. Jouannet, supra note 4, at 261-4.

7 M. Koskenniemi, From Apology to Utopia (CUP, 2005), at 98.

8 S. C. Neff, 'A Short History of International Law', in M. Evans (ed), International Law (OUP, 2006), 29, at 32. 
themselves constituted politically as states.$^{9}$ Suárez conceived of a rational basis of the law of nations as the moral and political unity of the human race $\left.\right|^{10}$ The sources of this law of nations were believed to be natural law principles, which were merely supplemented by tacit or express agreements between sovereign princes, which bound them in a personal capacity ${ }^{11}$ The law of nations as conceived by these early writers was all-embracing in character ${ }^{12}$ But this conception was not consistent with what came to be the orthodox view. Rather, drawing upon the work of Vattel, by the end of the $19^{\text {th }}$ century there was general agreement on the scope and subjects of international law, which implied inter-related doctrines of legal personality and designated the individual as an object of international law. It is useful to begin our traverse of history at that time.

\subsection{The $19^{\text {th }}$ century international legal system}

In the $19^{\text {th }}$ and early $20^{\text {th }}$ centuries, the established understanding of the international legal system was that its exclusive concern was relations between states, and that individuals were not subjects of, and could derive no rights or obligations directly from, international law. An examination of doctrine and practice in this period, across different subject-matter areas of international law, broadly supports this orthodox account. In general, international law did not engage individuals as right-holders or duty-bearers; nor did it recognise individual capacity to participate in the international system by bringing international claims. To the extent that the purpose was to protect or benefit individuals, this was achieved through the imposition of obligations on states, rather than by the conferral of international law rights on individuals.

Consistent with the orthodox account of the international legal system, two oft-cited antecedents for the direct engagement of individuals in the international legal system appear on closer inspection better characterised as arrange-

9 W. G. Grewe, The Epochs of International Law (M. Byers (trans)) (Walter de Gruyter, 2000), at 145-6.

10 F. Suárez, On Laws and God the Lawgiver (1612) (G.L. Williams (trans)) (Clarendon Press, 1944), Book II, Chapter 19.9, at 348-9.

11 F. de Vitoria, Political Writings (A. Pagden and L. Jeremy (eds)), (CUP, 1991), Relectio De Indis Question 3 Article 1, para. 4, at 280-1, Relectio De Potestate Civili Question 3 Article 1 paras. 15-17, at 32-6; Grotius, supra note 1, at 162. See also R. Lesaffer, "The Grotian Tradition Revisited: Change and Continuity in the History of International Law', (2002) 73 BYIL 103, at 123-4.

12 Kennedy, supra note 4, at 16-7, 42-5, 62-5 and 81-3; see also Koskenniemi, supra note 7, at 98-9; A. Nussbaum, supra note 3, at 86-7 and 108-9. 
ments regulating the conduct of individuals through the imposition of obligations on states. Piracy jure gentium was a special source of national jurisdiction which permitted states to prosecute individuals under their municipal law; international law did not directly impose obligations on individuals in respect of piracy; rather it endorsed the power of states to prosecute individuals ${ }^{13}$ The abolition of slavery also operated exclusively through inter-state obligations, imposed by treaty in which the individual was an object of beneficial regulation $\sqrt[14]{14}$

There were, however, a few exceptions. One was the Central American Court of Justice, which permitted individuals to seise the Court with questions of 'violations of treaties or conventions' ${ }^{15}$ The Court, which was in operation for a decade, examined five cases brought by individuals; the one case held admissible was decided in favour of the respondent state. There was no specific requirement that the relevant treaty or convention ascribe a particular right to an individual to form the basis of a claim; rather individuals were treated as having standing to complain that a state had violated an inter-state obligation. The Court thus treated individuals as having the capacity to bring international claims, but that capacity was not specifically linked to individuals as substantive right-bearers. ${ }^{16}$

A second exception was the treatment of armed opposition groups in civil conflict. Civil conflict caused problems for naval states when either or both of the lawful government and the insurgents claimed belligerent rights at sea. In response to these practical problems, maritime powers began to recognise belligerent rights ${ }^{17}$ Initially recognition of belligerency was linked

13 'Harvard Research Draft on Piracy' (1932) 26 AJIL Supplement 739, at 759. See also A.P. Rubin, The Law of Piracy (Naval War College Press, 1998), at 17, footnote 61; Viscount Sankey LC, In Re Piracy Jure Gentium, [1934] AC 586.

141926 Slavery Convention, 60 LNTS 253, No. 1414; 1956 Supplementary Convention on the Abolition of Slavery, the Slave Trade, and Institutions and Practices Similar to Slavery, 266 UNTS 3. As to the scope of the definition, see H. H. Wilson, 'Some Principal Aspects of British efforts to crush the African Slave Trade, 1807-1929' (1950) 44 AJIL 505, at 522-3. See generally J.A.C. Gutteridge, 'Supplementary Slavery Convention, 1956', (1957) 6 ICLQ 449.

15 Article 2, El Salvador- Nicaragua- Costa Rica- Honduras- Guatemala, 20 December 1907 (1908) 2 AJIL 231.

16 See M.O. Hudson, International Tribunals (Carnegie, 1944), at 34 . One case requesting a declaration of nullity of an election in Costa Rica was dismissed because it was not international in character; another case brought by Díaz (Nicaraguan) against Guatemala for wrongful arrest was dismissed for a failure to exhaust local remedies. See also C. J. Gutiérrez, La Corte de Justicia CentroAmericana (Biblioteca del Pensamiento Centroamericano, 1957).

17 See e.g., Britain's invocation of the law of neutrality in cautioning third states against providing aid to the insurgents during the American independence conflict (1775-83), which 
to recognition of at least de facto independence, since it was thought that only states could be the subject of belligerent (international law) rights. ${ }^{18}$ But beginning in the middle of the $19^{\text {th }}$ century, recognition of belligerency was detached from recognition of independence ${ }^{19}$ Thus belligerent (international law) rights were recognised for groups and individuals who did not necessarily have a valid claim to statehood. This occurred through a process of recognition by states: in this way, states remained gatekeepers of the international legal system; the ability of individuals to acquire international law rights was dependent on a specific intentional act by a state adopted as a matter of policy. At the time, there was a marked uncertainty as to how this practice could be reconciled with the way in which international law was conceived ${ }^{20}$ It appears that governments had an appreciation of the problem but did not fully engage with it. Rather, they responded to a practical problem by recognising that international law rights accrued to non-state entities, without confronting the question of how to reconcile that recognition with the established understanding of the international legal system. The engagement of the individual in the international legal system was not the end to which the recognition of belligerency and insurgency was directed; rather it was a by-product of a limited practice developed in response to a practical problem.

In contrast to these exceptional elements of international law during the $19^{\text {th }}$ century, the vast majority of doctrine and practice supported the established understanding of the framework of the international legal system at that

had the effect of designating the enemy as a separate state: 17 Geo 3 c. 9.

18 The fact that recognition of statehood was considered to be the basis of the acquisition of rights of belligerents in this early practice is also seen from an arbitration between the United States and Chile concerning the application of neutrality: see The Macedonian report in J.B. Moore, History and Digest of the International Arbitrations to which the United States has been a party (Government Printing Office, 1898), Volume II, at 1449ff. See discussion in A. McNair, 'The Law Relating to the Civil War in Spain', (1937) 53 LQR 471, at 479.

19 See e.g., the British treatment of the Greek rebellion against Turkey (1821-25), where the British Government claimed that the law of nations required it to recognise the free exercise of belligerent rights to Greek subjects of Turkey, separately from any obligation to recognise Greece as an independent state: Dispatch from Canning to Wellesley at Vienna, 31 December 1824, reproduced in H.A. Smith (ed), Great Britain and the Law of Nations Volume I-States (P.S. King \& Son Ltd, 1932), at 294-7, esp. 295. See discussion in H. Lauterpacht, Recognition in International Law (CUP, 1947), at 178-9, also 188. See also Opinion of Stephen Lushington, Doctors' Commons, 29 May 1823, reproduced in H. A. Smith (ed), Great Britain and the Law of Nations Volume I - States, at 291-3; Opinion of Stephen Lushington, Doctors' Commons, 26 June 1823, reproduced in ibid., at 293-4.

20 This is also reflected in the literature: see W.E. Hall, A Treatise on International Law, 3rd edn (Clardendon Press, 1890), at 35. 
time. Before 1919 there was no developed conception of individual criminal responsibility under international law; rather individual responsibility was a matter for domestic law and domestic processes ${ }^{21}$ In this period there was no notion of a general international law of human rights and where measures were taken in international law to benefit or protect individuals (such as the abolition of slavery and rules of warfare to alleviate the suffering of victims), they were effected through inter-state obligations in which the individual was an object of regulation, rather than a right-holder ${ }^{22}$

\subsection{The inter-war period}

In the inter-war period the established understanding of the international legal system was effectively unchanged: the theory held that individuals could not bear rights and duties under international law directly; nor was it possible for individuals to be characterised as subjects of international law. During this period there was significant development in respect of individual rights, but it effected no immediate transformation of the orthodox account of the international legal system. In 1928, the Permanent Court of International Justice (PCIJ) held in the Danzig Opinion that the object of a treaty 'may be the adoption by the Parties of some definite rules creating individual rights and obligations and enforceable by the national courts. ${ }^{23}$ While this is now commonly cited as recognising that individuals could hold international law rights and obligations, at the time this was not generally accepted as an accurate analysis-not least by influential members of the Court itself ${ }^{24}$ International legal doctrine maintained that individuals could not bear rights or obligations

21 Three categories of practice are often cited as antecedents of individual criminal responsibility under international law: first, individual responsibility for war crimes under national law; second, the 'international crime' of piracy; and third, internationalised courts for the prosecution of individuals. Although these practices may have claims as conceptual antecedents of international crimes, treating them as antecedents of individual responsibility under international law is questionable. See further K. Parlett, The Individual in the International Legal System (CUP, 2011), at 230-4.

22 See e.g., 1885 General Act of Berlin, Chapter II, Articles 4, 6, 9, Hertslet's Commercial Treaties (London, 1827-1925), Volume XVII, at 66ff; 1926 Slavery Convention, 60 LNTS 253; and 1956 Supplementary Convention on the Abolition of Slavery, the Slave Trade, and Institutions and Practices Similar to Slavery, 266 UNTS 3.

23 Jurisdiction of the Courts of Danzig (Pecuniary Claims of Danzig Railway Officials who have passed into the Polish Service, Against the Polish Railways Administration), PCIJ Reports Series B No 15, at 3, 17-8.

${ }^{24}$ D. Anzilotti, Cours de droit international (Librairie de Recueil Sirey, 1929), at 407-8, 133-4. 
directly under international law, and that individuals were objects, not subjects, of international law 25

But in practice, the idea of individuals being granted rights under treaties was taken up across several fields. This can be seen in relation to claims, where international claims tribunals and commissions were about evenly split between those processes in which individuals pursued claims directly, claims over which they had exclusive control, and those processes which operated on the basis of diplomatic protection, brought by a state in respect of injury to its national ${ }^{26}$ It is also seen in some of the often-cited antecedents of international human rights law, most clearly in the arrangements for protection of minorities and some of the rules relating to the treatment of refugees ${ }^{27}$ Further, some of the rules of humanitarian law treaties referred to rights for individuals, although it was unclear whether these rights were derived from international rather than national law 28

Moreover, where rights were conferred directly on individuals, the record suggests that this occurred as a means to some other particular end, rather than reflecting a conscious attempt to transform the structures of the international legal system. The development of rules concerned with the treatment of individuals within state borders, for example to protect minorities, was driven by concerns arising from the significant reorganisation of boundaries following the First World War, and was not the manifestation of an attempt to extend international law to an area traditionally considered as reserved to domestic jurisdiction. The engagement of individuals as rights-holders was the by-product of particular forces, not an end in itself.

In respect of the protection of individuals during the inter-war period, international law continued largely to express rules that benefited or protected individuals by the imposition of obligations on states, and without conferring direct rights on individuals. For example, the vast majority of the rules governing the conduct of international armed conflict continued to operate in terms of obligations imposed upon states to protect and benefit individuals,

25 See e.g., A. McNair, Oppenheim's International Law (Longmans, 1928), at 520.

26 See Parlett, supra note 21, at 65-84 and Appendix III to Chapter 2.

271919 Treaty of Versailles, UKTS 4 (Cmd. 153), Article 93. See also 1919 Treaty of St-Germain-en-Laye, UKTS 11 (Cmd. 400), Article 51; 1919 Treaty of Neuilly, UKTS 5 (Cmd. 522), Article 46; 1920 Treaty of Trianon, UKTS 10 (Cmd 896), Article 44. J. Robinson, Were the Minorities Treaties a Failure? (Institute of Jewish Affairs, 1943), at 19-20; I. L. Evans, 'The Protection of Minorities', (1923) 4 BYIL 95, at 104; United Nations Economic and Social Council, Commission on Human Rights, Study of the Legal Validity of the Undertakings Concerning Minorities, E/CN.4/367, 7 April 1950, at 2-3.

${ }^{28}$ See 1929 Geneva Convention on Prisoners of War, 118 LNTS 343, Articles 62 and 64. 
and were not expressed in terms of rights. ${ }^{29}$ Some of the early arrangements for refugees and the International Labour Organization conventions also imposed obligations upon states without conferring correlative rights on individuals ${ }^{30}$ Individuals were therefore protected in two ways: either as indirect beneficiaries of obligations imposed upon states, or as direct right-bearers under international treaties. There is no obvious pattern between the application of one or other of these frameworks, and in particular there seems to have been no consideration given to the question of which framework was better suited to the type of benefit or protection.

In this period, a principle of individual responsibility under international law was implied by the Treaty of Versailles: for the Kaiser, responsibility was foreshadowed for violations of the 'sanctity of treaties ${ }^{31}$ whereas for all other individuals, responsibility was envisaged for violations of the laws and customs of war. However, these provisions of the Treaty of Versailles were not executed, and in practice individual responsibility was only enforced under domestic law, through (manifestly defective) domestic processes ${ }^{32}$ No conception of individual obligations directly under international law arose in this period in any other context.

In general the developments in the inter-war period reflect a sense of transition and change in the structures of the international legal system. This is particularly evidenced in the reluctance of some commentators to accept the apparent consequences of the Permanent Court's Opinion in Danzig. Yet in practice-on the part of states and tribunals-that reluctance was not manifested; Danzig was frequently cited in support of individual rights under treaties, enforceable before international tribunals, and a significant proportion of the arrangements for the protection of individuals under the auspices of the League used the structural device of individual rights to achieve that protection.

${ }^{29}$ See 1929 Geneva Convention for the Amelioration of the Condition of the Wounded and Sick in Armies in the Field, 118 LNTS 30, Articles 1, 5, 9 and 12.

30 See generally A.W.B. Simpson, Human Rights and the End of Empire: Britain and the Genesis of the European Convention (OUP, 2001), at 149-51; D. A. Morse, The Origin and Evolution of the I.L.O. and Its Role in the World Community (Humphrey Press, 1969); W. C. Jenks, Human Rights and International Labour Standards (Stevens, 1960); J. T. Shotwell, The Origins of the International Labour Organization (Columbia University Press, 1934).

311919 Treaty of Versailles, UKTS 4 (Cmd. 153), Article 227.

32 See generally C. Mullins, The Leipzig Trials: An Account of the War Criminals' Trials and a Study of German Mentality (H.G. \& G. Witherby, 1921). 


\subsection{The post-1945 international legal system}

In the period between 1945 and the present day, it has come to be accepted in orthodox doctrine that individuals may derive rights and obligations directly under international law, which may be enforced in international tribunals. The effect of Danzig was only realised in this period; and eventually the International Court of Justice (ICJ) held that treaties may confer rights on individuals by plain language ${ }^{33}$ In doctrine the bearing of rights and obligations has been more closely linked with international legal personality: it has come to be acknowledged that to the extent that individuals possess rights and duties, they are subjects of international law.

In practice individuals have been accorded rights under treaties across a range of areas of international law. This is most clearly the case in international human rights law: universal and regional conventions treat individuals as holding rights which they may enforce in an international tribunal having jurisdiction, or through an international forum with an established complaint mechanism ${ }^{34}$ In internal armed conflict, individuals may possess both rights and obligations under common Article 3 of the Geneva Conventions 35 and Protocol II Additional to the 1949 Geneva Conventions and Relating to the Protection of Victims of Non-International Armed Conflicts ${ }^{36}$ or applicable customary international humanitarian law ${ }^{37}$ In the context of protection of foreign investment, although it depends on the particular bilateral investment treaty (BIT), it has been accepted that the terms of a BIT, interpreted in their context and in light of the treaty's object and purpose, may confer substantive rights on individual investors coterminous with the host state's obligations of treatment ${ }^{38}$ In addition, it is also more common for states to establish treaty mechanisms which confer on individuals the capacity to enforce

33 LaGrand (Germany v United Status of America), Judgment, ICJ Reports 2001, p. 466, at 492-4 para. 77.

34 See generally P.G. Lauren, The Evolution of International Human Rights: Visions Seen (University of Pennsylvania Press, 2003), 147ff.

35 G.I.A.D. Draper, 'The Geneva Conventions of 1949’ (1965-I) 114 Hague Recueil 60, at 96.

361977 Protocol II Additional to the Geneva Conventions of 12 August 1949 and Relating to the Protection of Victims of Non-International Armed Conflicts, 1125 UNTS 606. Y. Sandoz, C. Swinarski and B. Zimmermann (eds.), Commentary on the Protocol Additional to the Geneva Conventions (ICRC/Martinus Nijhoff, 1987), at 1345, para. 4444.

37 Case Concerning Military and Paramilitary Activities in and against Nicaragua (Nicaragua $v$ United States of America), Merits, ICJ Reports 1986, p. 14, at 114, para. 218. Prosecutor v Tadic, Judgment of Appeals Chamber (Jurisdiction), Case IT-94-1-AR72, 2 October 1995.

38 See e.g., The Republic of Ecuador v Occidental Exploration and Production Company [2005] EWHC 774 (Comm), at para. 61. 
their own rights before international tribunals or to seek redress through international complaint mechanisms. It is generally accepted that individuals have at least a procedural right to seek international arbitration claiming in respect of violation of a BIT, provided it contains a relevant dispute resolution clause ${ }^{39}$ Both individual rights and individual capacities to enforce rights are dependent on a specific grant of right or capacity by states which might be given prospectively (as in the case of an offer to arbitrate in a BIT) or retrospectively (as in the case of the Iran-US Claims Tribunal and the UN Compensation Commission): access to the international legal system has remained within the exclusive control of states.

Although it is common to accord direct rights to individuals, rules for the protection of individuals do not operate exclusively through this structural device. A number of rules intended to benefit individuals impose obligations on states without conferring rights on individuals. For example, international humanitarian law applicable in international armed conflict generally establishes standards of treatment as obligations on individuals and does not confer direct rights on individuals ${ }_{40}^{40}$ While in the inter-war period it appeared that the choice between one or other of these structural devices was not reasoned, in this period it has been argued that one or other framework may be used because it is better adapted or more effective in relation to the particular rule ${ }^{41}$ It has been suggested that in international armed conflict, a framework of standards is more effective than an individual rights framework in ensuring the protection of individuals. This may explain why international humanitarian law has retained its inter-state framework, rather than operating within an individual rights framework.

While individuals are given rights across a range of fields, the only developed conception of individual obligations has occurred in relation to international crimes. After Nuremberg, the principle of individual responsibility for international crimes was generally accepted but there was some reluctance to accept that this necessarily entailed that individuals were directly subject to international law. This reluctance is reminiscent of the reluctance which sur-

39 For example, Article 8 of the Sri Lanka Model BIT states that a dispute 'may be submitted upon request of the investor...': Sri Lanka Model BIT, reproduced in C. McLachlan, L. Shore and M. Weiniger, International Investment Arbitration: Substantive Principles (OUP, 2007), Appendix 9, 427. Article 1120 of NAFTA provides that 'a disputing investor may submit the claim to arbitration': 1992 North American Free Trade Agreement, 32 ILM 612 (1993). 1994 Energy Charter Treaty, 2080 UNTS 100, Article 26.

40 See Parlett, supra note 21, at 181-96.

41 R. Provost, International Human Rights and Humanitarian Law (CUP, 2002), at 54-6. 
rounded individual rights in the inter-war period, the full ramifications of the Permanent Court's opinion in Danzig only forming part of the orthodox account some twenty years later. With the work of the International Criminal Tribunal for the Former Yugoslavia, International Criminal Tribunal for Rwanda and the International Criminal Court (ICC), there can now be no question that individual responsibility for international crimes is imposed by international law and without the interposition of domestic law.

The development of individual responsibility for international crimes which is rightly traced to Nuremberg-occurred in response to the practical question of what ought to be done with the major war criminals. While it is common to present the Nuremberg Charter and trial as a kind of inevitability in response to the horrors of the Second World War, the historical record presents a rather different picture. For the British and the Americans, there was a reluctance to commit to a judicial process rather than summary executions and judicial treatment was pursued because Stalin was not amenable to a political disposition. Again, an international military tribunal was a political solution to a practical problem, and individual responsibility under international law was a by-product of that solution. In general, there is a sense that the development of individual responsibility under international law for international crimes was a graft onto the international legal system motivated by practical and political concerns, and that it was not inevitable even in September 1944, less than 12 months before the Nuremberg Charter was signed ${ }^{42}$

Notable by its absence is any capacity for individuals to formally participate in the process by which they acquire rights and obligations, or more generally in the making of international law. To the extent that individuals acquire rights, obligations and capacities, it is through a passive process, directed primarily, if not exclusively, by states. Individuals cannot agree to the conferral of rights or the imposition of obligations, for example, through participating in international treaties. In general there has been little concern as to whether individuals consent to bearing rights, obligations and capacities. In the context

42 Initially both the British and the Americans were reluctant to commit to a judicial process for the treatment of the major war criminals. In September 1944 Churchill and Roosevelt agreed to propose to Stalin that a number of the top Nazi leaders be executed, including Hitler and Himmler (see FRUS, The Conference of Quebec 1944 (1972), at 467). On 22 October Churchill reported that Stalin was not amenable to a political disposition of the Nazi leaders and was firmly insistent on a trial if death sentences were to be imposed. But the British continued to reject the prospect of establishing an international court by treaty, preferring trial before national military courts. It was not until the San Francisco Conference that the British Cabinet instructed its delegation that there was no utility in continuing to oppose a trial if the US and the USSR were committed to it. 
of armed opposition groups in internal armed conflict, it has been suggested that these groups and individuals acquire rights and obligations through a process of consent, similar to that required for third party states to acquire rights and obligations under treaties. In other contexts there has been no consideration of whether individuals so consent. This absence might be explained in some circumstances by considerations of beneficence which imply that consent is irrelevant; in other contexts, particularly where obligations are imposed on individuals, the question of consent may be more significant. Moreover this demonstrates the differential treatment of states and individuals: between active subjects and passive recipients of rights and obligations in the international legal system.

In the extent to which individuals exercise rights, individuals have a more active role, but even in this context the exercise of rights is dependent on a pre-existing grant (which like any treaty is revocable in certain circumstances). In international claims practice, whether an individual submits a claim to arbitration (for example, in relation to foreign investment) is a question solely within that individual's control and dependent on its resources. In this sense, the individual is not completely passive, but the extent to which it is capable of acting in the international legal system is still conditioned on a grant of capacity by a state. So while the post- 1945 period may be perceived as one which has witnessed the rise of the individual, it must be emphasised that states have remained central and in control of the extent to which individuals may engage in the international legal system: the extent to which individuals are given rights, obligations and capacities is dependent on a specific grant from the primary actors in the international legal system, dominated by states.

\section{Forces for structural change: solutions above theories}

So, taking account of this brief summary of the development of international law vis-à-vis individuals, what can be said about the raison d'être of the engagement of the individual in international law? (This reverts to the first controversy identified above, namely the extent to which the structural change in international law to accommodate individuals has been motivated by theoretical discourse.)

The international legal system has experienced structural transition as a result of the need to manage and address practical problems rather than 
resulting from any deliberate attempt to effect a structural transformation. The international legal system does not appear to be developing along a smooth trajectory from a state-centric international law to a more inclusive international legal system ${ }^{43}$ The picture which emerges suggests, rather, that states manage practical questions as they arise by adaptation of the international legal system, and as a result of those practical solutions the international legal system may be transformed. That transformation does not seem to inhere in any particular theoretical framework or any preconceived notions of a fixed set of goals for international law.

There are three prominent examples.

The first is the development of individual criminal responsibility. In an orthodox account of international criminal law, the move from the concept of war crimes prosecuted in national courts to international crimes prosecuted in an international court at Nuremberg is presented as if it were a fait accompli, a natural progression for an international law concerned with the commission of appalling crimes on a mass scale. But the historical record reveals that it was only at the last gasp that it was agreed to deal with the major war criminals through a judicial process, and an internationalised one at that. The Allies had made no commitment to judicial treatment of the major war criminals: in September 1944, less than a year before the Nuremberg Charter was signed, Churchill and Roosevelt agreed that the top Nazi leaders would be summarily executed. Only when it became apparent that the Soviets were firmly opposed to political disposition was it agreed that these persons should be dealt with by judicial process. Thus the Nuremberg Tribunal-subsequently understood as having a transformative effect on the structures of the international legal system-came into being because it represented a political solution to a practical problem. The transformation of the structures of the international legal system was a side-wind.

The second example is the development of international human rights law. Since 1945, there has been incremental development in that field in response to a range of factors, including the atrocities of the Second World War. But the imposition of binding obligations on states (corresponding to individual rights and enforceable in international fora) through international treaties was in pursuit of generalised goals, including the protection of the individual from ill-treatment by his or her own state. Human rights law is acknowledged as having had a transformative effect on the international legal system, yet it came

43 See e.g. the discussion in C. Grossman and D.D. Bradlow, 'Are We Being Propelled Towards a People-Centred Transnational Legal Order?', (1993-1994) 9 Am. U. J. Intl L. \& Pol'y 1. 
about because of steps taken to address the problem of protection of individuals within domestic jurisdiction (and in the context of the failure of the minorities system), not because of a conscious decision to change the structures of the international legal system.

A final example can be found in the device of diplomatic protection, and the recent developments in the law relating to the protection of foreign investments. An increase in the movement of persons across borders and the need to protect those persons and property resulted in the development of an international standard of minimum treatment of aliens, which essentially gave states of nationality an actionable interest in the treatment of their nationals. In more recent times a desire to more effectively protect foreign investment (and thus to encourage foreign investment) has resulted in treaty regimes for the protection of foreign investments. These developments were a consequence of addressing particular problems, rather than originating from a desire to elevate the individual to a particular status in international law, or to transform the international legal system. The ensuing structural transformation was a by-product, not a cause.

To argue that the structures of the international legal system have been transformed in response to practical problems is not to say that theorising serves no useful purpose, or that the international legal system at any particular point in time cannot be explained by reference to theory. It is rather to suggest that there are (and have been) a range of possible futures for the international legal system, and that the extent to which those futures are realised is highly contingent, and in the end dominated by the interests of states. There is a kind of unpredictability inherent in the development of the international legal system, but that unpredictability reflects a strength in the system's potential to flexibly respond to the needs of the international community.

\section{International legal personality as the measure of engagement}

As noted at the outset, the traditional device used to explain the relationship of entities to the international legal system has been the doctrine of the subjects of international law, which divides entities into binary categories of 'object' and 'subject'. In the $19^{\text {th }}$ century international legal system, it was said that subjects of international law were states 'solely and exclusively.44 In the inter-war

$\overline{44}$ Oppenheim, supra note 4 , at $18-9, \$ 13$. 
period the possibility of the League of Nations being a subject of international law since it had 'distinctive international rights and duties' was raised but not resolved ${ }^{45}$ In the post-1945 international legal system it has been accepted that to the extent that entities other than states 'directly possess' rights, powers and duties in international law they may be regarded as subjects of international law ${ }^{46}$ The opening of the doctrine of subjects is generally traced to the 1949 Reparation Opinion, where the ICJ introduced a variegated approach to the subject categorisation, holding that the extent of a subject's rights, duties and capacities in the international legal system 'depends on the needs of the [international] community. ${ }^{47}$ Thus the subjects of international law are not identical: states possess the full range of rights, duties and attendant capacities, whereas other subjects may have more limited rights, obligations and capacities.

The variegated approach to subjects of international law has the consequence that there are qualitatively different subjects. At one end of the spectrum, a state, which has a complete ability to acquire rights, obligations and capacities and to enter into legal relations is apt to be described as a subject of international law; while at the other end of the spectrum, a non-governmental organisation which is recognised by a single inter-governmental organisation as having standing before it is also apt to be described as a subject of international law. There must be significant qualitative differences between the two ends of the spectrum. Yet in orthodox doctrine there are no criteria for locating subjects according to the measure of their rights, obligations and capacities. Thus the variegated approach to the doctrine of subjects has exposed a fundamental deficiency of the doctrine: that the identifier 'subject' has no objective and meaningful content, since it denotes no particular capacities: hence it fails to provide any revealing description of the relationship of the entity to the international legal system. As Eli Lauterpacht has noted:

...there is no definition of personality in international law which is sufficiently comprehensive to apply in some constructive or realistic way to all the different types of entities which operate in the international field 48

\footnotetext{
45 McNair, supra note 25, at 133-4.

46 Jennings and Watts, supra note 4 , at $16, \$ 7$.

47 Reparation for Injuries Suffered in the Services of the United Nations, Advisory Opinion, ICJ Reports 1949, p. 174, at 178.

48 E. Lauterpacht, 'The Development of the Law of International Organization by the Decisions of International Tribunals', (1976-IV) 152 Hague Recueil 377, at 403.
} 
Several alternatives for locating entities within the international legal system have been proposed. The late Professor D.P. O'Connell suggested that the term 'international legal personality' should be discarded in favour of identifying particular capacities of relevant entities ${ }^{49}$ Dame Rosalyn Higgins, who rejects the subject/object dichotomy as having 'no credible reality and... no functional purpose $\sqrt{50}$ argues that within the process of international law there are a variety of participants who make claims corresponding to their values. ${ }^{51}$ Within this framework, what matters is not the designated status of an entity but its actual exercise of functions ${ }^{52}$ Professor McCorquodale ${ }^{53}$ also argues in favour of the notion of participation, suggesting that it connotes greater flexibility than the binary categories of subjects and objects, and that this flexibility reflects current doctrine, as reflected in the ICJ's treatment of international legal personality $[5$ A similar approach is advocated by Christoph Schreuer, who prefers to examine the relationship of entities to the international system by an examination of their functions 55

These notions of capacities, participation and functions are conceptually useful because they suggest that what is significant is not the formal status of an entity, but its actual ability to engage in the international legal system in a given context. Whether an entity can act in the international legal system in a particular way is dependent not on its formal status, but rather on that entity's capacities and functions. Since the generalised identifier of 'subject' is not revealing of any particular ability to act in the international legal system, an examination of the capacities, participations or functions of an entity must be undertaken to determine whether and to what extent an entity is able to act or engage in the international legal system.

Where the notions of capacities, participation and functions do not assist is in locating entities in the international legal system: in distinguishing between qualitatively different subjects, from those entities bearing a single international

49 D.P. O'Connell, International Law, Volume I (Stevens and Sons, 1970), at 83.

50 R. Higgins, Problems and Process: International Law and How We Use It (OUP, 1994), at 49.

51 Ibid., 50.

52 R. Higgins, 'Conceptual thinking about the individual in international law', (1979) 24 New York Law School L Rev 11, at 16.

53 R. McCorquodale, 'The Individual and the International Legal System', in M. Evans (ed), supra note 8, 307, at 311; R. McCorquodale, 'An Inclusive International Legal System', (2004) 17 LJIL 477 , at 481 .

${ }^{54}$ Reparation for Injuries Suffered in the Services of the United Nations, Advisory Opinion, ICJ Reports 1949, p. 174, at 178.

55 C. Schreuer, 'The Waning of the Sovereign State: Towards a New Paradigm for International Law', (1994) 4 EJIL 447, at 453. 
right or obligation at one of the spectrum, to entities with the full range of rights, responsibilities and capacities at the other.

Dividing the subjects of international law into 'states' and 'others' might seem overly simplistic, but it is nevertheless helpful to identify which capacities distinguish subjects at one of the spectrum from subjects at the other end of the spectrum. In particular, two capacities would appear to distinguish entities which have autonomy and independence in the international legal system (termed, for convenience, 'autonomous subjects') from entities which have only limited and passive capacities in the international legal system ('passive subjects'). The first is the extent to which an entity has control over its own receipt of rights, obligations and capacities: whether it receives capacities only when it consents or whether capacities are imposed upon it without regard for its consent. An entity which has this type of control would have capacity to prevent international law from being imposed upon it by other international law-makers, without its consent. The second capacity is an entity's control over the delegation of functions and capacities to other entities: the extent to which it can control access to the international legal system. Entities which enjoy this capacity may be described as 'gatekeepers'. Entities which have both these capacities have an independent capacity to participate in the international legal system, whereas entities which possess neither may only participate in the international legal system at the instigation of and with the consent of these independent subjects. The latter are passive to the extent that they have no independent capacity to participate or exercise functions in the international legal system.

In the period since 1945 it has become part of the orthodox understanding of the international legal system that (a) individuals can have rights and duties flowing directly from international law, and (b) to the extent that individuals have rights, duties and capacities under international law, individuals are subjects of international law ${ }^{56}$ But qualitatively the capacities of individuals

\footnotetext{
56 Jennings and Watts, supra note 4 , at 16 , \$7. See also O'Connell, supra note 49, at 107-8; Higgins, supra note 52, at 16; McCorquodale (2006), supra note 53, at 329; McCorquodale (2004), supra note 53. In 2002 Judge Cancado Trinidade, in a separate opinion in the Inter-American Court of Human Rights, emphasised that it was now impossible to sustain the opposite view, that individuals were not subjects of international law: 'The doctrinal trend which still insists in denying to individuals the condition of subjects of International Law is based on a definition of these latter, requiring from them not only to possess rights and obligations emanated from International Law, but also to participate in the process of creation of its norms and of the compliance with them. It so occurs that this rigid definition does not sustain itself...': Advisory Opinion on the Legal Status and Human Rights of the Child, Inter-American Court of Human Rights, Advisory Opinion OC-17/02, 28 August 2002,
} 
have been limited to receiving rights, obligations and particular capacities through processes in which they have no formal rights of participation. Thus the way in which individuals may participate and exercise functions in the international legal system operates on a kind of dependency: it only occurs at the instigation and with the consent of other subjects of international law which control access to the international legal system. Individual rights, obligations and capacities are imposed on individuals without particular regard for their consent in the process. Individuals have no meaningful or formal capacity to participate in the process by which international law is created. Thus individuals remain subordinated in the international system, suspended between object and independent or autonomous subject.

\section{The move towards individualism and away from the state: normative critiques}

The final controversy to be discussed is the normative question: to what extent is the move away from the state, and the increased prominence of the individual in international law, a cause to be championed?

In my view, enthusiasm for the increased prominence of the individual in international law must be qualified. This is for three reasons.

First, giving individuals direct rights and obligations, and conferring upon them capacities to enforce their rights, is not the only available device for the protection of individuals. They may be benefitted or protected in other ways. The system of diplomatic protection has not been outright replaced by regimes for protection of foreign investment or human rights; rather those newer regimes continue to operate alongside the existing regimes. It seems unlikely that diplomatic protection will be replaced by these regimes or others; it continues to serve a useful purpose in the international system. In this way new developments in the international legal system can be seen to have resulted in a series of grafts on the existing structure of the international legal system, rather than a replacement of the existing structure. Thus the international legal system has developed multiple structural devices which can be used in a particular situation to address particular problems. In any given situation, more than one structural device may offer possible answers to those problems.

Second, and following from the first, individual interests in a particular field may be best protected by a framework which does not necessarily accord them

(2004) 11 IHRR 510, Concurring Opinion of Judge Cancado Trinidade, at paras 26-7. 
rights of participation. In relation to humanitarian law, it has been suggested that a framework of standards of treatment functions more effectively than a framework of individual rights. Direct participation by individuals is one model which operates to protect individual interests, but the assumption that it is the preferable model for that protection is open to question-and it can certainly not be assumed to be the exclusive model. Individuals might have direct interests in having the standard of minimum treatment of aliens respected, but this is not to say that individuals should have standing to bring claims which traditionally belonged to the realm of diplomatic protection to the ICJ. Individuals might well have direct interests in respect for the rules of warfare, but this does not necessitate that those individuals have substantive rights which would entitle them to reparation in case of violation. In those contexts the state construct still serves some useful purpose. Claims that the international legal system is moving away from a state-centric model and that better protection of individuals is necessarily achieved through a framework of individual rights overlook the possibility that in a particular context, a framework closely associated with a state-centric international legal system may be more effective in achieving benefits for and protection of individuals.

Finally, it should not be forgotten that individuals may also have rights-and effective remedies-through domestic law. The primacy of domestic law and remedies has been emphasized in recent times: it is reflected in the complementarity provisions of the ICC Statute, and it has been mentioned in the context of reforms to the European Court of Human Rights, an institution which is struggling to deal with the number of individual applications pending before it. In the end it may be more beneficial to individuals to focus efforts on improving domestic rights and remedies-and making them more consistent with international law standards-than to seek elevated standing in the international legal system in respect of each and every area in which individuals have interests.

Undoubtedly the international legal system of the 21st century is less state-centric that the international legal system of the $19^{\text {th }}$ century, and the individual has a more prominent role in international law today than in Vattel's conceptualisation. However, even today, states still have a dominant role in the international legal system, as autonomous and independent subjects of international law, while individuals, although also subjects, have much more limited capacity to engage in the international legal system. Furthermore, while individuals have some direct rights in international law in various-and ever expanding - fields, it should not be assumed that direct rights necessarily connote better protection in a particular context, than would be possible under 
a state-centred model of international law. The state is not about to 'wither away ${ }^{\sqrt{57}}$ Rather, its dominating position in the international legal system has been reinforced while some limited rights and obligations have been developed for individuals, who remain subordinated in the international legal system.

57 E. Stein, 'International Law in Internal Law: Towards Internationalization of CentralEastern European Constitutions?', (1994) 88 AJIL 427, at 450. 